\title{
En uvanlig idrettsskade
}
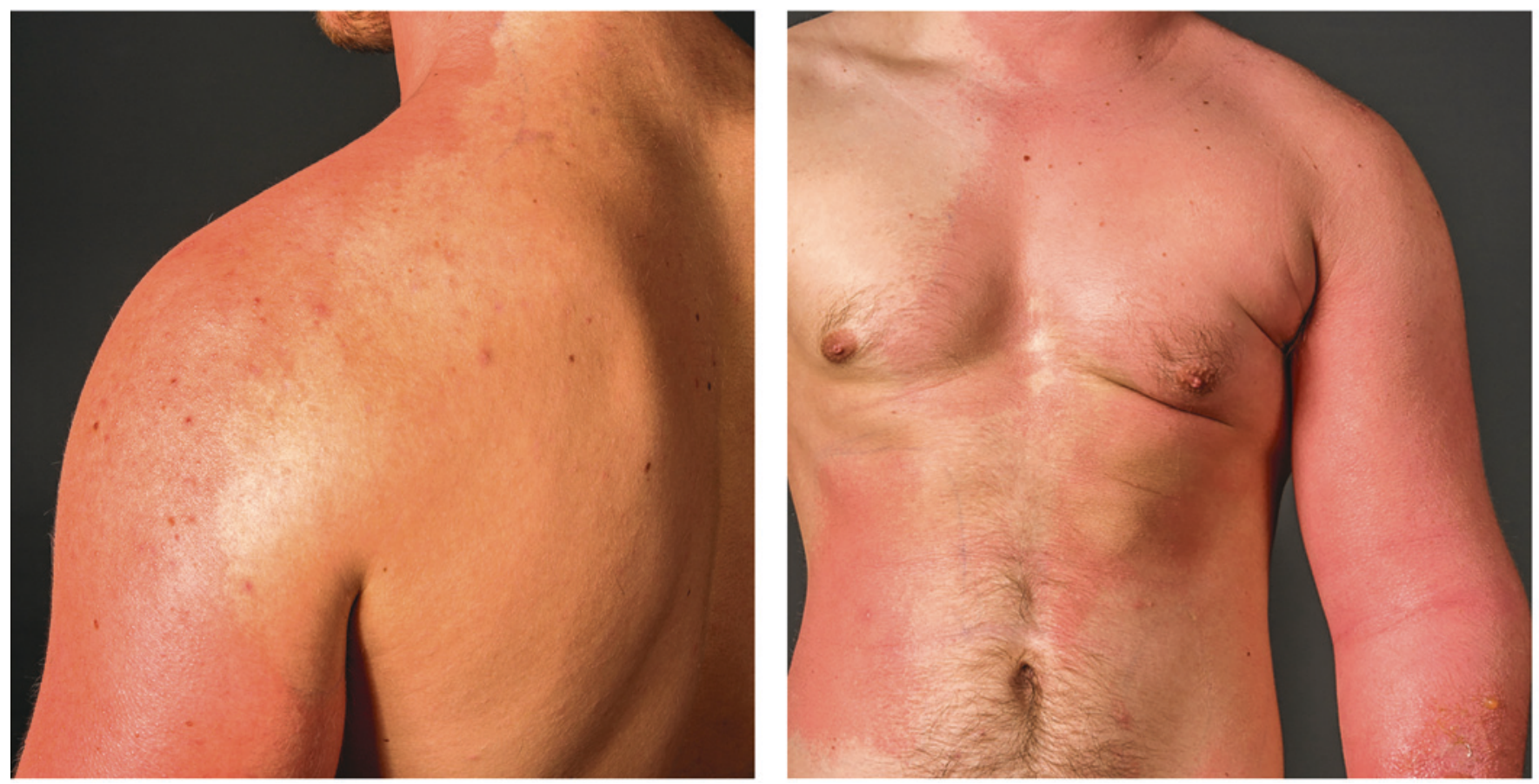

Begge foto: Øystein H. Horgmo, Universitetet i Oslo

En gutt i tenårene utviklet smerter, erytem, blemmer og hevelse på venstre side av kroppen fem dager etter en brytekamp. Han ble innlagt $i$ sitt lokalsykehus hvor han ved innkomst var i god allmenntilstand, afebril, med et normalt antall hvite blodceller og negativt CRP-nivå. SSSS (staphylococcal scalded skin syndrome) ble mistenkt, og han fikk intravenøs antibiotika. Samtidig ble han henvist til dermatologisk avdeling.

Ved undersøkelse hadde han utslett på venstre overekstremitet og på venstre side av truncus, hals og på venstre øre (bildene). Utslettet var skarpt avgrenset mot normal hud. Sykehistorie og klinisk undersøkelse ga mistanke om kontakteksem. Pasienten ble behandlet med $40 \mathrm{mg}$ prednisolon nedtrappende over én uke. Utslettet ble raskt bedre etter noen dager.

Kontakteksem er en relativt vanlig tilstand i befolkningen og den vanligste yrkesrelaterte dermatosen. Det kan være utfordrende å skille mellom irritativt og allergisk kontakteksem. Denne pasienten hadde ved en tidligere anledning opplevd å få lignende reaksjon på hendene etter bruk av boksehansker. Det ble derfor lagt en standard epikutantest (lappetest) på pasientens rygg med de hyppigst forekommende allergenene (1). Aller- giske reaksjoner angis som milde, moderate eller kraftige. Epikutantesten ga kraftig reaksjon på parafenylendiamin (PPD), som er et fargestoff som brukes blant annet i klesfarging, hårfargemidler, kosmetikk, gummi, plast og skokremer (2). Det var også reaksjon på tekstilfargen oransje, mens det var en mild reaksjon på tekstilfargen rød.

Vi oppfatter pasientens utslett som et kontaktallergisk eksem basert på sykehistorie og funn. Det er vanskelig å avgjøre nøyaktig hva pasienten reagerte på, men i dette tilfellet synes det mest sannsynlig at reaksjonen skyldtes farge i tekstil brukt av ham eller motstanderen. Allergenvandring fra tekstiler krever fuktig og tett miljø. Denne kasuistikken er videre et godt eksempel på at kontakteksem ikke rent sjelden blir oppfattet som infeksjon.

Pasienten har gitt samtykke til at artikkelen blir publisert.

\section{Syed Mohammad Husain Rizvi}

mohammad.rizvi@ous-hf.no

Jon Anders Halvorsen

Per Helsing

Seksjon for hudsykdommer

Oslo universitetssykehus, Rikshospitalet
Syed Mohammad Husain Rizvi (f. 1983) er lege i spesialisering i hud- og veneriske sykdommer.

Forfatter har fylt ut ICMJE-skjemaet og oppgir ingen interessekonflikter.

Jon Anders Halvorsen er ph.d, spesialist i hudog veneriske sykdommer, overlege og førsteamanuensis.

Forfatter har fylt ut ICMJE-skjemaet og oppgir ingen interessekonflikter.

Per Helsing (f. 1958) er spesialist i hudsykdommer og overlege.

Forfatter har fylt ut ICMJE-skjemaet og oppgir ingen interessekonflikter.

\section{Litteratur}

1. Johansen JD, Aalto-Korte K, Agner T et al. European Society of Contact Dermatitis guideline for diagnostic patch testing - recommendations on best practice. Contact Dermat 2015; 73: 195-221.

2. Steinkjer B, Stangeland KZ, Mikkelsen CS. Kontaktallergi mot hennatatovering. Tidsskr Nor Legeforen 2011; 131: 581-2. 